have acquired infection with a monkey virus. These three viruses-the first papovavirus from the patient with progressive multifocal leucoencephalopathy, BK virus, and the SV 40 isolates from the last two patients-are identical in appearance by electron microscopy, and it is clearly of considerable importance to compare them serologically to see if they are antigenically related. It is disappointing that no results of serological tests on the virus from progressive multifocal leucoencephalopathy and BK virus have so far been published.

The BK virus described by S. D. Gardner and her colleagues had been isolated from a Sudanese patient who had received a kidney transplant from his brother. Both donor and recipient had antibody to the virus before the operation, though the patient developed a rise in antibody titre after it. This suggests that the infection was a reactivation due to the immunosuppressive therapy required after transplantation. In a report 13 January, in the B.M.f. (p. 77) Dr. Sylvia Gardner now shows that BK virus is no stranger to Britain. She found that the incidence of antibody to BK virus rose from $37 \%$ in preschool children aged from 1 to 5 years to $73 \%$ in children aged from 4 to 6 years, while $83 \%$ of the children aged 6 to 10 years had antibody. It is clear from these results that infection with BK virus is widespread in Britain and that it is usually acquired in childhood. Among the adults tested more than $70 \%$ had antibody to the virus. Dr. Gardner also tested paired sera from children with a variety of undiagnosed illnesses which were thought to be possible cases of virus infection in the hope of finding a disease associated with $\mathrm{BK}$ virus infection. But none of these sera showed a rising titre of antibody to the virus, so that there is so far no evidence that BK virus causes illness in children.

These interesting results show that most people are infected with BK virus in childhood, but they also suggest that the virus is probably of low pathogenicity in that it has not so far been found to cause clinical symptoms in previously healthy persons. It would be of great interest to know if, like the other human papovaviruses, BK virus can cause progressive multifocal leucoencephalopathy in debilitated patients. The epidemiology of SV 40 is entirely different from that of BK virus. Rhesus monkeys are the natural hosts of SV 40 and human infection with the virus is uncommon. However, antibodies to SV 40 have been found in $2 \%$ to $6.5 \%$ of groups of people in the United States and in India who had no known exposure to either monkeys or poliovaccines which were contaminated with the virus. ${ }^{67}$ These results suggest that there may be some limited circulation of SV 40 - or a human virus serologically similar to it-among human populations. This might explain the rare case of progressive multifocal leucoencephalopathy due to SV 40, but further studies on the source of infection with SV 40 in man are clearly required. The discovery of BK virus also raises the question of whether there are unknown viruses which infect man but rarely if ever produce disease. A reasonable guess would be that there probably are.

1 Padgett, B. L.. Walker, D. L., ZuRhein, G. M., Eckroade, R. J., and Dessel, B. H., Lancet, 1971, 1, 1257.

2 Gardner, S. D., Field, A. M., Coleman, D. V., and Hulme, B., Lancet, 1971, 1, 1253.

3 Sweet, B. H., and Hillman. M. R. Proceedings of the Society for Experimental Biology and Medicine, 1960, 105, 420.

4 Weiner, L. P., et al., New England Fournal of Medicine, 1972, 286, 385.

5 Penney, J. B., Weiner, L. P., Herndon, R. M., Narayan, O., and Johnson, R. T., Science, 1972, 178, 60 .

6 Shah, K., Ozer, H. L., Pond, H. S., Palma, L. D., and Murphy, G. P., Nature, 1971, 231, 448.

7 Shah, K. V., American fournal of Epidemiology, 1972, 95, 199.

\section{Antenatal Injury}

In English law at present there is a doubt whether a child with an injury caused before birth by someone's negligence can sue for damages. Last week the Law Commission exexpressed its "provisional view" that it should be able to recover damages from that person and declared that early legislation is desirable. ${ }^{1}$

If this proposal becomes law doctors will face a fresh risk of actions for damages for negligence in the treatment given to a pregnant woman either for her benefit or for the benefit of the fetus. This may be a natural if onerous addition to the legal hazards that every practising doctor has to bear today. But many legal tangles are foreseeable. A baby may be born and survive in an injured condition after damage caused in utero by drugs, $x$ rays, abortifacients, or surgical procedures. The injury may be evident at birth, or become so in childhood, or not appear until adult life. And in some circumstances the causal connexion between the injury and the alleged negligent action could be the subject of long arguments between experts on lines that are all too familiar in the less complicated circumstances of actions for damages today against doctors for their treatment of an individual patient. Whether a particular drug or exposure to $x$ rays caused a disease that became evident only in later childhood or adult life could be very much a matter of probabilities, on which courts would need to hear some fairly complex statistics.

A further question to be argued in many, cases would be the balance struck between benefit to the mother and risk to the fetus. To what extent does the mother bear responsibility by accepting treatment? The life and health of the mother traditionally take priority over that of the fetus if the circumstances of the case reach the extremity of choice. What then is the relation between a child who had been injured in utero by medical treatment and his mother? Clearly there are aspects of the Law Commission's proposals that deserve thorough study.

1 Law Commission, Published Working Paper No. 47. Published by the Law Commission, Conquest House, 37-38 John Street, Theobalds Road, London WCIN 2BQ, which will be grateful for comments received before 20 April. See also discussion by our Legal Correspondent at p. 244 .

\section{Controlling Inflation- Second Stage}

The White Paper on the second stage of the Government's attack on inflation raises as many questions as it answers and the B.M.A. will be shortly meeting the Government and the Review Body to find out where doctors stand. The Government's declared aims are: "to steady prices, to be fair, and to sustain a faster rate of economic growth" and in working out its policy the Government wants to "allow flexibility in operation to meet differing circumstances." If this therapy shows real signs of success then the profession will, no doubt, accept the uncomfortable side effects. For success would not only benefit doctors but should in the long run result in more resources for the N.H.S.- and it badly needs them.

"Four per cent plus $£ 1$ a week" fits neatly into the headlines, but doctors will want to know how the small print of 